\title{
Some Characteristics of Interspecific Hybrids between Dioscorea japonica Thunb. and Dioscorea opposita Thunb ${ }^{1}$.
}

\author{
Hajime Araki, Takashi Harada and Toshiro Yakuwa \\ Faculty of Agriculture, Hokkaido University, Saporo 060 Japan
}

\begin{abstract}
Summary
In 1975, we obtained 2 seeds which appeared to be hybrids from a natural cross between $D$. japonica and D.opposita (cv. Nagaimo). Two seedlings were produced from them by embryo culture. In 1980, chromosome number, sex, structure of flowers, shape of leaves and underground tubers and quality of tubers of the 2 plants were investigated. The results obtained are summarized as follows.

1. Both the 2 plants showed the chromosome number of 110 and proved to be hybrids between D. japonica $(2 \mathrm{n}=80)$ and D. opposita $(2 \mathrm{n}=140)$.

2. The 2 hybrids were both male plants and the morphological structure of flowers was similar to that of D.opposita, but pollen fertility was lower than that of D.opposita.

3. The tubers of the hybrids were as long as those of D.opposita, intermediate in thickness between those of the parents and more mucilaginous than those of D. opposita.

Thus, a possibility was suggested to get new Dioscoreas with superior characteristics by hybridization between D. japonica and D.opposita.
\end{abstract}

\section{Introduction}

Dioscorea opposita cv. Nagaimo is cultivated widely in Japan, and its yield per unit area is high, while its textural qualities are inferior to those of other cultivars of the same species such as 'Yamatoimo' and 'Ichoimo'. On the other hand, D. japonica (Jinenjo in Japanese) has excellent qualities, but its tuber is not so thick as that of D. opposita (This scientific name denotes hereafter cv. Nagaimo alone) and the yield is low. In addition, a kind of virus infecting D. opposita does not infect D. japonica. No report has been published concerning the hybridization between D. japonica and $D$. opposita.

The female plants of $D$. japonica and male plants of D.opposita have been planted alternately with each other in the experimental field of Hokkaido University in Sapporo since

1 Received for publication December 21, 1982.

Studies on the botanical characteristics of genus Dioscorea IV.
1972. The female plants of D. japonica were collected at Gonohe in Aomori Prefecture and the male plants of D.opposita were collected at Yubari in Hokkaido. In 1975, 2 seeds were obtained from a female plant of D. japonica. These 2 seeds were considered to be hybrids between D. japonica and $D$. opposita because there was no male plant except those of D.opposita in the field. In 1976, 2 seedlings were obtained from these seeds by embryo culture, and proved to be hybrids according to the evalution of their chromosome numbers. In the present paper, they are designated as Hybrid 1 and Hybrid 2 , and some of their characteristics were investigated in comparison with those of D. japonica and D.opposita.

\section{Materials and Methods}

From 1977 to 1979, the tubers of Hybrid 1 and Hybrid 2 were devided into 12 and 9 pieces, respectively. In April 1980, these pieces were germinated in a green house and in June, they were planted in a field at 
Yubari in Hokkaido-one of the producing centers of D.opposita. In Yubari, volcanic ash soil prevails. It is so loose and deep that the tubers can elongate free of physical obstacles, and it seemed to be suitable for investigation of the shape of tubers.

At sprouting, the chromosome number was observed with root tips to confirm whether or not these plants are hybrids between $D$. japonica and D.opposita. In the summer, the sex and the characteristics of flowers and leaves were investigated. The tubers were harvested on November 5 and their shapes were observed. The details of methods used for observations were described below.

\section{Chromosome number}

The tubers were exposed to $0^{\circ} \mathrm{C}$ for 3 months to break the dormancy. Thereafter, they were divided into seed pieces about $50 \mathrm{~g}$ in weight and planted in a rooting bed. When they rooted after 3 weeks, the adventitious root tips were used for observation of the chromosome. For that purpose, the root tips were kept at $0^{\circ} \mathrm{C}$ for 24 hours and then fixed in Östergren and Heneen's fluid for 24 hours(9). They were stained with acetocarmin and observed by the squash method.

2. Characteristics of flowers and leaves On August 24, the flowers were collected and fixed in FAA. The structure of flowers was observed with paraffin sections stained with Mayer's hemalum. Pollen fertility was determined by staining with acetocarmin. Observation of leaves was carried out using the 15 th or upper leaves from the plant
Table 1. Comparison of pollen fertility among Hybrid 1 and 2 and their male parents, D. opposita.

\begin{tabular}{lr}
\hline Line & Pollen fertility (\%) \\
\hline D.opposita & $94.8 \mathrm{a}^{\mathbf{z}}$ \\
Hybrid 1 & $81.5 \mathrm{~b}$ \\
Hybrid 2 & $61.7 \mathrm{c}$ \\
\hline
\end{tabular}

z Mean separation by Duncan's new multiple range test, $5 \%$ level.

base, because they were less variable in shape, color and luster.

3. Characteristics of underground tubers

The length, diameter and weight of tubers and the appearance of their surface were investigated. The water content and the mucilage of the flesh of tubers were also investigated for quality. Ten $g$ of grated tuber was dried at $70^{\circ} \mathrm{C}$ for 24 hours in a drying chamber equipped with a fan. Then the weight of the dry matter was measured and water content was calculated. Fifty g of tuber blocks were homogenized together with $50 \mathrm{ml}$ of water for 30 seconds. After leaving for $1,5,10$ and 20 minutes, $15 \mathrm{~g}$ of the homogenate was dropped through a glass tube ( $1 \mathrm{~m}$ long having $6 \mathrm{~mm}$ bore) and the time required for the downward flow of homogenized sample through the tube was recorded in minutes.

\section{Results}

\section{Chromosome number}

All chromosomes observed in this study were very small and granular ranging from

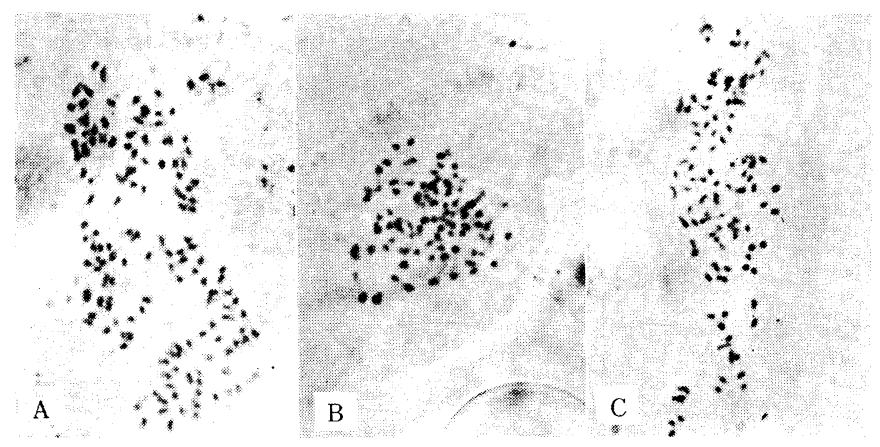

Fig. 1. Comparison of chromosome number.
A : D. opposita, male $(2 \mathrm{n}=140)$,
B : D. japonica, female $(2 \mathrm{n}=80)$,
C : hybrids between D. japonica and D.opposita $(2 \mathrm{n}=110)$. 

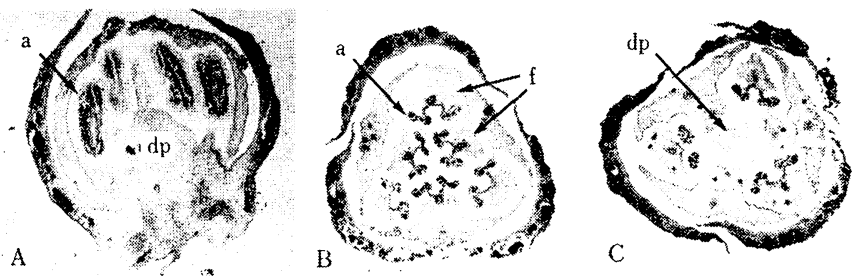

Fig. 2. Structure of the male flower of hybrid (Hybrid 1) between D.japonica and D.opposita. $A$ : vertical section, $B, C:$ cross section, a : anthers and pollens, $f:$ filaments, $\mathrm{dp}$ : degenerated pistil,

A
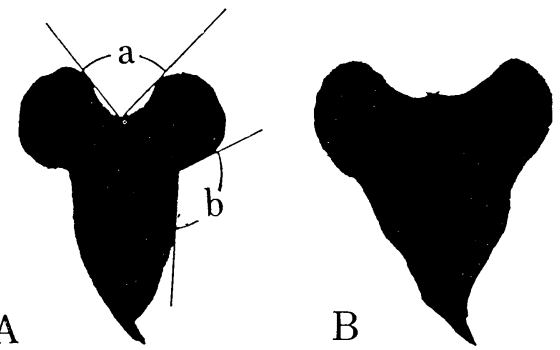

$\mathrm{C}$
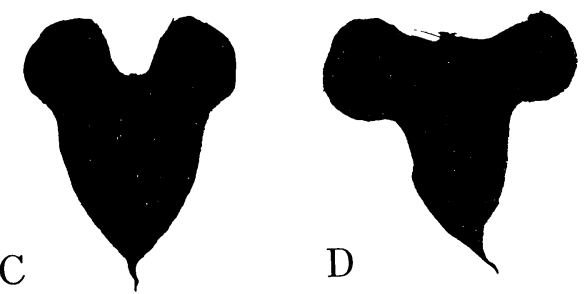

Fig. 3. Comparison of the shape of leaves.

A : D.opposita, B:D.japonica,

C : Hybrid 1, D : Hybrid 2.

a : angle of the sinus on leafbase,

$\mathrm{b}$ : angle of the rounded sinus on margin.

1 to $1.5 \mu \mathrm{m}$ in length. The chromosome number was 140 in the male plant of $D$. opposita and 80 in the female plant of $D$. japonica (unpublished), while it was 110 in the 2 plants newly obtained (Fig. 1). From this result, these 2 plants proved to be hybrids between D. japonica and D.opposita.

2. Characteristics of the flowers and leaves

Both Hybrid 1 and 2 were male plants and developed male flowers alone. The flowers were similar in shape to those of D.opposita (Fig. 2). The flowers of these hybrids were larger in size than those of D.opposita. Thus, the male flowers of D.opposita were 2.5 to $3.0 \mathrm{~mm}$ in width, whereas those of Hybrid 1 and 2 were 3.7 and $3.3 \mathrm{~mm}$ in width, respectively.

The pollen fertility was significantly lower in the hybrids than D.opposita (Table 1).

The typical shapes of leaves observed are shown in Fig. 3. The leaf of D.opposita is deeply cordate with rounded sinus and acuminates at the top of the leaf, while that of D. japonica is simple and acuminate. The leaf shape of Dioscorea can be characterized by the angles of sinus on the leaf base (Fig, 3-a) and on the leaf margin (Fig. 3-b). In Hylrid 1, the former (Fig. 3-a) was small as
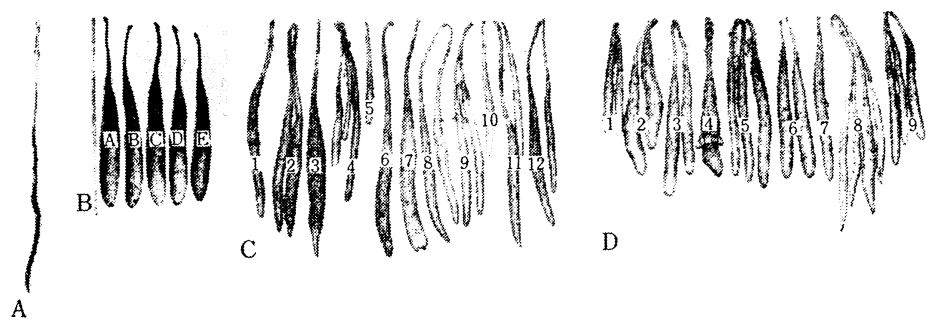

Fig. 4. Comparison of the shape of underground tubers A : D. japonica, B : D.opposita, C : Hybrid 1, D : Hybrid 2. 
Table 2. Comparison of some characteristics of underground tubers among Hybrid 1 and 2 and their parents.

\begin{tabular}{lcccc}
\hline & \multicolumn{4}{c}{ Line } \\
\cline { 2 - 5 } Character & D. opposita & D. japonica & Hybrid 1 & Hybrid 2 \\
\hline Length $(\mathrm{cm})$ & $50 \sim 70$ & $60 \sim 100$ & $60 \sim 80$ & $40 \sim 60$ \\
NL/TL & $0.22 \sim 0.40$ & - & $0.29 \sim 0.40$ & $0.22 \sim 0.33$ \\
Diameter of tuber $(\mathrm{cm})$ & $5.0 \sim 8.0$ & $1.5 \sim 3.0$ & $2.5 \sim 5.0$ & $2.5 \sim 5.0$ \\
TD/ND & $2.0 \sim 5.0$ & 1.0 & $1.5 \sim 3.0$ & $2.0 \sim 3.5$ \\
\hline
\end{tabular}

$z$ Ratio of neck length to tuber length.

$\mathrm{y}$ Ratio of tuber to neck in diameter.

in D.opposita and the latter (Fig. 3-b) was large as in D. japonica. On the other hand, in Hybrid 2, the former was large as in $D$. japonica and the latter was small as in $D$. opposita. The leaves of Hybrid 1 and 2 were both waxy dark green, and 0.28 and $0.30 \mathrm{~mm}$ in thickness respectively, being as thick as that of D.opposita.

3. Shape of underground tubers.

The shapes and some characteristics of underground tubers are shown in Fig. 4 and Table 2, respectively. The tuber of $D$. opposita had a slender neck which could be distinguished clearly from the other part. But in D. japonica, the tuber was uniformly slender throughout its length and the neck was not clearly distinguished. While in the hybrids, the neck could not be easily distinguished from the other part and the ratio of it to the whole tuber in length differed little from that of D.opposita. The diameter of tuber in the hybrids was smaller than that of $D . o p$ posita but larger than that of D. japonica. The tubers of the hybrids were heavier than those of D. japonica and as heavy as those of $D$. opposita. Especially in Hybrid 1, one of the largest tubers weighed as much as $930 \mathrm{~g}$. The tubers of Hybrid 1 showed a tendency

Table 3. Comparison of water content in underground tubers among Hybrid 1 and 2 and their parents.

\begin{tabular}{cc} 
Line & Water content $(\%)$ \\
\hline D. opposita & $80.3 \mathrm{a}^{\mathrm{z}}$ \\
D. japonica & $64.5 \mathrm{~b}$ \\
Hybrid 1 & $61.8 \mathrm{bc}$ \\
Hybrid 2 & $67.8 \mathrm{c}$ \\
\hline
\end{tabular}

${ }^{2}$ Mean separation by Duncan's new multiple range test, $5 \%$ level. to be more slender than those of Hybrid 2 . The tubers of the hybrids were round or sharp at their tips. That of D.opposita was round, while that of $D$. japonica was sharp at the tip. The surface of the tubers was more rough in the hybrids than $D$.opposita and D. japonica.

4. Water content of underground tubers The water content of underground tubers

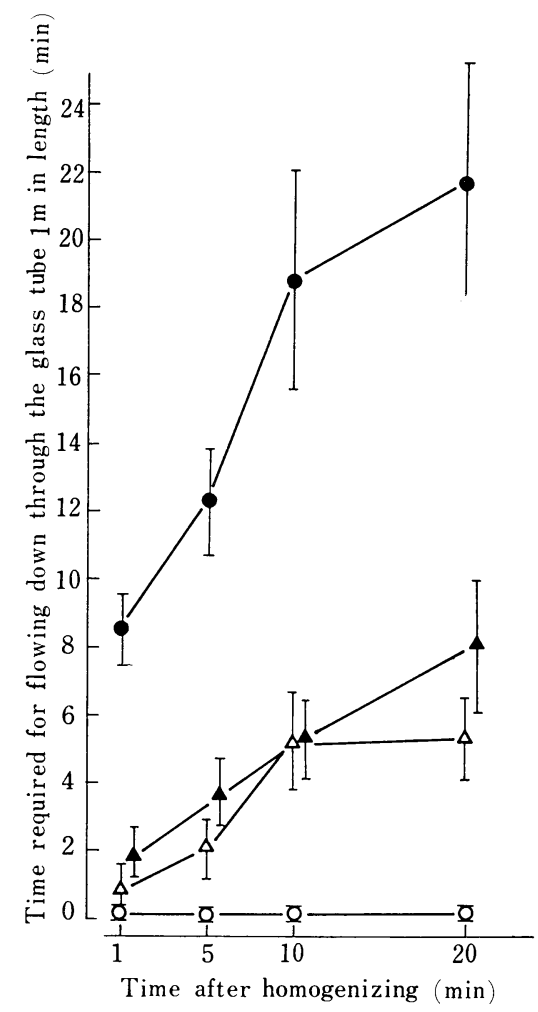

Fig. 5. Comparison of the mucilage of the flesh of tubers.

(O) D.opposita,

$(\triangle)$ Hybrid 1, Vertical lines represent SD

(A) Hybrid 2 . 
of the hybrids was similar to that of $D$. japonica and much lower than that of $D$. opposita (Table 3).

5. Mucilage of the flesh of underground tubers

The homogenate of flesh of D.opposita was waterly and $15 \mathrm{~g}$ of it flowed down through the glass tube in 5 to 6 seconds, while that of D. japonica required 8 to 22 minutes because of high mucilage. In contrast, in the case of the hybrids, the time required was intermediate between $D . o p$ posita and D. japonica (Fig. 5). It was confirmed that in Hybrid 1 and 2, the flesh of the tubers was more mucilagenous than D. opposita but not so mucilagenous as $D$. japonica.

In D.opposita, the time required for the downward flow of the homogenized sample through the glass tube was almost constant regardless of the time after homogenization. While in D.japonica and the hybrids, it increased with time after homogenization (Fig. 5).

\section{Discussion}

In the parent plants and their hybrids, the chromosome numbers were all multiples of 10 as reported for Old World species $(3,4$, $5,6,7,8,11,12,13)$. As in other species of Dioscorea, karyotype analysis was unsuccessful because the chromosomes observed were too small. It was confirmed that the 2 plants obtained were hybrids between D.japonica and D.opposita, because their chromosome number was 110 , which is the mean of 80 in D. japonica and 140 in D.opposita.

As described in the introduction, both D. japonica and D.opposita have some merits and some demerits as cultivated species. The hybrids were intermediate between the parents with respect to the shape and quality of tubers. This result indicates a possibility to improve demerits of each species through hybridization.

As to disease resistance to viruses, about $20 \%$ of D. opposita were infected with some kind of viruses, but no symptoms due to viruses were observed in the hybrid plants grown in the same field. This phenomenon is noticeable and whether or not the hybrids are infected with the viruses which attack $D$. japonica is now under investigation.

Untill now, the breeding of Dioscorea has been carried out mainly by selection of the plants with excellent characteristics in connection with yield, keeping quality and so on. Some trials have been reported on the breeding of yam through hybridization(1,2, 10). The purposes of these studies were to increase the yield of tubers and the content of steroidal sapogenin. In 1966, Martin et al. partially succeeded in crossing within the New World species and obtained hybrids from 13 combinations, but they always failed in crossing between New and Old World species or within Old World species(2). Rao et al. found out 3 combinations within New World species which produced seeds with normal germination ability(10). In this experiment, we succeeded in crossing between 2 Old World species, D. japonica and D.opposita. The hybrids obtained by Martin et al. were intermediate between their parents in some characters of vegetative organs and reproductive organs and they exhibited poor physiological control of critical growth phases such as the juvenile phase. Our hybrids were intermediate between their parents in some characters of vegetetive organs as in the case of Martin et al., but not in reproductive organs. Thus, the male flowers of Hybrid 1 and 2 were larger than those of D.opposita.

In general, it is difficult, but not impossible, to obtain hybrid seeds when $D$. japonica and D.opposita are planted alternately with each other and crossed by open or artificial pollination, In fact, in 1975, 2 seeds were obtained by open pollination. In breeding of Dioscorea, it is important to clarify the environmental conditions enhancing the seed formation.

Fortunately, many hybrid seeds were obtained between D. japonica and D.opposita by open pollination in 1978. The plants with wide variations in some chracters are expected to be obtained from these seeds. 


\section{Acknowledgement}

The authors wish to express their gratitude to Dr. M. Suzuki, Faculty of Agriculture, Hokkaido University and Dr. Y. Takeuchi, Aburahi Laboratories of Shionogi Co. for their helpful advice in the observation of the chromosomes. Thanks are also due to Mr. S. Aizawa for lending his field for this experiment and Mr. N. Kasai for his cooperation in this experiment.

\section{Literature Cited}

1. Martin, F. W. and E. Cabanillas. 1963. A wild hybrid of sapogenin-bearing Dioscorea species. Bull. Torrey Bot. Club $90: 232-237$.

2. Martin, F. W. and E. Cabanillas. 1966. The hydrids of some sapogenin-bearing Dioscorea species. Amer. J. Bot. $53: 350-358$.

3. MARTin, F. W. and S. ORTIZ. 1963. Chromosome numbers and behavior in some species of Dioscorea. Cytologia 28: 96-101.

4. NaKajima, G. 1931. Chromosome numbers in some crops and wild angiosprems. Jap. J. Genetics. $7: 211-218$.
5. NAKAJima, G. 1933. Chromosome numbers in some angiosperms. Jap. J. Genetics. $9: 1-5$.

6. NAKAJIMA, G. 1942. Cytological studies in some flowering dioecious plant, with special reference to the sex chromosomes. Cytologia $12: 262-267$.

7. RAMACHANDRAN, K. 1962. Studies on the cytology and sex determination of the Dioscoreaceae. J. Ind. Bot. Soc. 41:93-98

8. RAMACHANDRAN, K. 1968. Cytological studies in Dioscoreaceae. Cytologia $33: 401-410$.

9. ÖstergRen, G. and W. K. HENEEN. 1962. A squash technique for chromosome morphological studies. Hereditas $48: 332-341$.

10. RAO, V. R., R. K. BAMmi and G. S. RANDHAWA. 1973. Interspecific hydridization in the genus Dioscorea. Ann. Bot. $37: 395-401$.

11. Sharma, A. K. and N. DeEPESH. 1956. Polyploidy in Dioscorea. Genetica 28:112-120.

12. Sмith, B. W. 1937. Note on the cytology and distribution of Dioscoreaceae. Bull. Torrey Bot. Club $64: 112-120$.

13. TAKEUChI, Y., T. IWAO and A. AKahORI. 1970. Chromosome numbers of some Japanese Dioscorea species. Acta Phytotax. Geobot. $24: 168-173$.

\title{
ジネンジョとヤマノイモとの種間雑種の特性について
}

\author{
荒木 肇・原田 隆・八鍬利郎 \\ 北海道大学農学部 060 札幌市
}

摘要

1975 年にジネンジョ（市）とヤマノイモ('ナガイモ' ○）との自然交配で 2 個の種子が得られ，胚培養により 2 株の実生を育成した。これらの実生を，ウイルスなど に感染しないように隔離栽培し，切り芋法により堌殖さ せた. 1980 年には着花し，地上部拉よび地下部において それぞれ特徵ある形状を示したので，種々の特性を雨親 との比較で調査した.

1. 実生の染色体数 は $2 \mathrm{n}=110$ で, ジネンジョ（2n =80) と 'ナガイモ' $(2 \mathrm{n}=140)$ の中間の数で, 染色 体数の上から両種の種間雑種であることが確認された。

2. 雑種実生は 2 株とも雄株で, ‘ナガイモ’ と同じ構
造の雄花を着生したが, 花粉稳性は‘ナガイモ’のそれよ り低かった。

3. 芋の形状は ‘ナガイモ’ 程度の長さになり, ジネン ジョよりもはるかに太くなった。 また，水分含量や粘 りなどの品質に関してジネンジョと'ナガイモ’の中間 的な特徴を示し, ‘ナガイモ’より水分が少なく，粘りも 強くなった。このように雑種実生は, 形態と品質の両面 そ叔いて, ジネンジョと'ナガイモ’の短所とされる点が 改善されて和り, 今後ヤマノイモ属の栽培種の育種を進 める上で極めて注目される。 